\title{
EFFECT OF FAMILY SUPPORT ON SELF EFFICACY AMONG PREGNANT WOMEN WITH ANEMIA
}

\author{
Sri Handayani'), Anggorowati'), Fery Agusman MM33) \\ 1)Masters Program in Nursing, Universitas Diponegoro \\ 2)Department of Maternity Nursing, Universitas Diponegoro \\ 3)Department of Community Nursing, School of Health Sciences \\ Karya Husada Semarang
}

\begin{abstract}
Background: As Albert Bandura has defined it, self-efficacy is an individual's belief in his or her innate ability to achieve goals. It is a personal judgment of how well one can execute courses of action required to deal with prospective situations. This study aimed to determine the effect of family support on self-efficacy among pregnant women with anemia to recover from anemia.

Subjects and Method: This was a quasi-experiment before and after with no control design conducted at Puskesmas (community of health center) Gambirsari, Banjarsari, Surakarta, Central Java, from May to July 2018. A sample of 33 pregnant women with anemia were selected for this study. The dependent variable was self-efficacy to recover from anemia. The independent variable was family support through System Information of Self Treatment Anemia (SISTA) application. The data were collected by questionnaire and analyzed by chi square test.

Results: Self-efficacy of pregnant women after family support (Mean=15.70; $\mathrm{SD}=$ 2.44) was higher than before family support (Mean=4.87; $\mathrm{SD}=1.88$ ), and it was statistically significant $(\mathrm{p}=0.023)$.

Conclusion: Family support via SISTA application is effective to help improve self-efficacy of pregnant women to recover from anemia.
\end{abstract}

Keywords: family support, SISTA application, self-efficacy, pregnant women

\section{Correspondence:}

Sri Handayani. Masters Program in Nursing, Universitas Diponegoro, Jl. Prof. Soedarto, Tembalang, Semarang, Central Java.

Email: hanshibasaki89@gmail.com. Mobile: 085786973183.

The 4th International Conference on Public Health Best Western Premier Hotel, Solo, Indonesia, August 29-30, 2018 | 177 https://doi.org/10.26911/theicph.2018.03.08 